\author{
Marika Pirveli \\ University of Szczecin \\ Social Geography and Spatial Organization Unit \\ e-mail: mariam.pirveli@usz.edu.pl
}

\title{
The Urban Language (Urbslingua) - Phenomenological Method
}

JEL codes: A13, B4, D7, D04, O3, A1

Keywords: phenomenology, culture map, urban language, morphosign, method

Summary. This manuscript proposes a concept of an urban language, urbslingua, embedded in the urban studies. It is a tool with the use which one can identify spatial phenomena in need of research, and which helps to place the fragment of space under study in the holistic picture of the city. The city has been treated as a spatial message, the urban space being a multilayered spatial text; the text is written with morphosigns. A morphosign (language equivalent for a grapheme) is an indivisible structural element of the urbanized space. Morphosigns emergent from the urban form (defined by ISUF) denote designates of all types of human activities the spatial reflections of which are situated within the confines of the urban space. The urban space is their synthesis and binder. Morphosigns are bound together by culture which is a navigator of urban spatial order, i.e. a syntax.

\section{Introduction}

The city focuses its attention of numerous scientific disciplines. As those disciplines develop to become more specialised and internally diversified, and narrower and more specialised study areas merge to form interdisciplinary fields, the city becomes their object of study as well (in urban sociology; history of building cities; urban planning; urban geography; urban economy; etc.). Depending on the approach favoured by an individual researcher, studies aimed at developing 
theoretical constructs or working out practical solutions can be problem-oriented (holistic) or centred on a single aspect (partial). The multiple complexity of the urban space, however, always requires an interdisciplinary approach, whereby individual studied aspects are viewed in a holistic context.

This text proposes a concept of an urban language, urbslingua, embedded in the urban studies. It is a tool with the use of which one can identify spatial phenomena in need of research, and which helps to place the fragment of space under study in the holistic picture of the city.

The city has been treated as a spatial message, the urban space being a multilayered spatial text. The text is written with morphosigns. A morphosign which is a language equivalent for a grapheme is an indivisible structural element of the urbanized space. Morphosigns emergent from the urban form (defined by International Seminar on Urban Form, ISUF, 2017) denote designates of all types of human activities the spatial reflections of which are situated within the confines of the urban space; the urban space is their synthesis and binder. Morphosigns are bound together by culture which is a navigator of urban spatial order, i.e. a syntax.

Culture is understood in terms of Edward Hall's communication theory of culture as a silent language. An individual, while functioning within a defined territory, transforms his/her activities into culture by shaping those activities in the way he/she thinks fit and are in agreement with local environmental conditions. In the urban language, the universal human needs are systematised into Primary Message Systems (PMS); they correspond with the culture map as their matrix. The PMS or types of human activities, pervading one another, form the substance of culture and have their spatial designates.

\section{A hypothetical city}

A human settlement is a form of socio-spatial organization. Its substance is conditioned and shaped by diverse factors operating under different circumstances. The human settlement itself (a city as well as conditions and factors modelling the city), change in time and space, and are determined by a culture of the city builder represents. The city builder is a human being and institutions he/she establishes (the family, a market operator representing state and private sectors, a community, a local group, a city itself). This suggests that the individual first transforms the space according to principles and canons of his/her own culture and grants it a certain shape, status, and function in the process; then, the individual behaves and acts according to the laws of the space he/she appropriated by using it and building within it.

The city and the village, a pair of human settlements, are not abstract constructs. These are names of certain locations where people live permanently or just visit, or they denote sites of origin of something or of accumulation of something. 
They are types of settlements humans create to adapt a fragment of the available space to fit their needs and to confer spatial characters upon it, to make the space comfortable to be in.

Each human settlement, regardless of a historical period, features buildings, streets, squares, roads, sidewalks, greenery, utilities, and means of transportation. It hosts diverse institutions functioning as school, post office, police, surgery, hospital, management office, place for interment of the deceased, eatery, hotel, factory, and exchange and purchase-sale site. Spatial distribution of inhabitants and institutions creates the socio-topography. Spatial systems and cubic elements constructed above- or underground have their own physiognomic characters resulting from materials used for construction and finishing and from the architectural style. The resultant structure is embedded in the local relief, with a due consideration to the local conditions: geology (determining the type of fundaments required), climate (determining the structure of walls, wall openings, roofs, stability of the materials used, and the architectural style), characteristics and demography of the local community. The inhabitants, attending to their needs, move in the streets and perform actions resulting from routine practices. ${ }^{1}$ They visit sites, institutions, buildings. Signs direct people to relevant institutions. The street gallery ${ }^{2}$ displays graphic, light and written messages. Some have authors while others are anonymous. Interpersonal relations in the public space convey a lot of information about the place in question. The place has its own dialect. A human settlement emits diverse sounds. Each time of the day and night has its own sound. The sound brings information about the time of the day in the city (or in the village). Sounds of conversations carried out by passers-by, of vehicles, and of birds differ in intensity depending on the time of the day. In addition, the content of the sound brings important information as well, e.g. about the street language being used. The place has its smells, emanating mostly from rooms and buildings, but also evidencing the type and quality of vehicles (means of transportation in general), sanitary standards, personal hygiene products and perfumes used. The human settlement

\footnotetext{
${ }^{1}$ Routine practices, a concept adopted from A. Giddens, correspond to a human being's dietary habits, clothing, behavioural patterns, or frequenting in favourite places. These are attributes of a lifestyle defined as a more or less integrated system of practices a human being adheres to not only because they are useful, but also because they provide a material shape to individual identity narratives. In this way, according to A. Giddens, the Weberian Strände (i.e. life's chances) have become a lifestyle as understood in a conventional way, that is as a concept covering the spheres of consumption and work habits (Giddens, 2002, pp. 112-122).

${ }^{2}$ The street gallery stems from the word gallery which has a number of meanings. In architecture, a gallery is among others an elongated external or internal space on upper floors of a building, extending along the length of the wall; a gallery may be a collection of objects or characteristic items displaying peculiar properties (Galeria, 2017). The street gallery denotes a space created in the city streets, surrounded by building façades, and filled with a collection of different objects and characteristic items displaying peculiar features [see footnote 13 in Pirveli 2008, p. 57].
} 
has also its colours. These depend on climatic conditions, vegetation, colours of the façades, advertisements, night- and daytime lighting, and the colour of human skin and clothing. Each person present in a founded reality expresses their attitude towards the surroundings. All people decide on the climate (atmosphere) of the place. All that taken together forms a profile of the founded reality in a fragment of the urban space. This is a hypothetical founded reality modelled by a social grouping (community Figure 1).

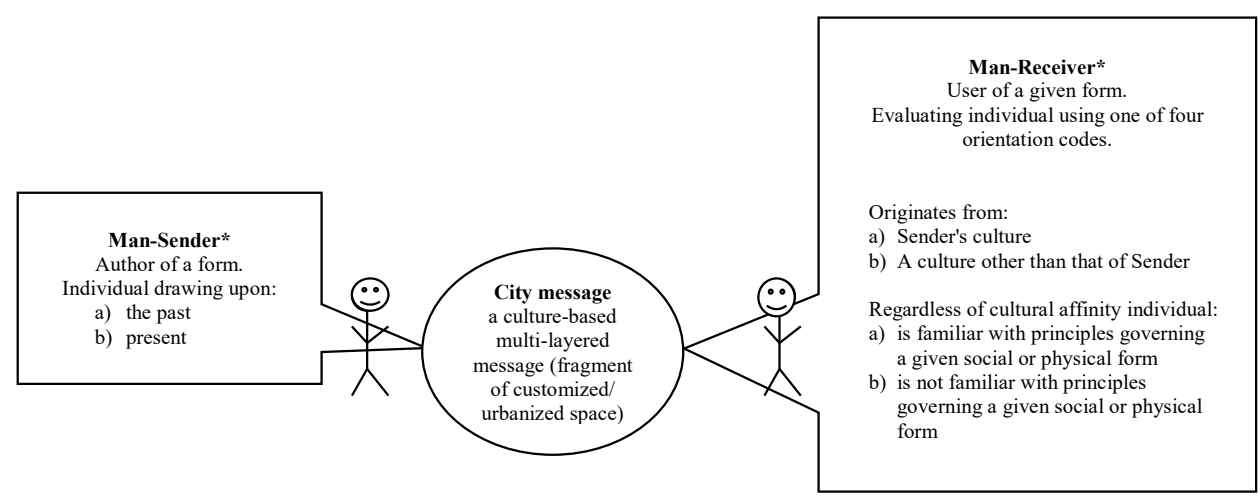

* The concept of Man is social rather than statistical category. Depending on the context, it may denote a person, a social group, a community, etc.

Figure1. Man-Sender and Man-Receiver

Source: Pirveli, 2008, p. 137.

In a case study, the hypothetical city described above and shown in Figure 1 ceases to be an abstract concept, since it is translated into concrete messages left by a community of active and acting human beings. When we describe particular cases of customized places, the hypothetical founded reality becomes filled with content, and the physical space takes on non-spatial value (Wallis, 2001); it becomes memorable and identifies the site. After some time, the hitherto-existing designates human activity, a substance of social facts, generate a new context. That context lies at the foot of and models all the subsequent processes. Anyone who comes in any contact with the customized space, comes into contact with evidence of activity of another human being who, consciously or unconsciously, acts according to the dictates of his/her "own" culture. 


\section{Communication theory of culture}

According the Communication Theory of Culture, culture evolves from pre-culture. It consists of biological activities of an individual which serve to satisfy the universal human needs (sleep, movement, communication, mating, learning, defence, feeding, recreation, playing, construction of tools with the use of which it is possible to broaden the scope of one's senses). A human being functioning within a territory has transformed his/her own biological activities (i.e. pre-culture) into culture by shaping them into a most convenient form, compatible with local environmental conditions (Hall, 1987, pp. 184-185).

E. Hall operationalized culture and systematized its substances based on its best-known component: the language. While setting off from the anthropological definition of culture ${ }^{3}$ he developed its sociological definition stating that "culture is communication and communication is culture" (Hall, 1987, p.184). As a result, he juxtaposed the categories of "language" and "culture". E. Hall identified ten Primary Message Systems (PMS. Hall, 1987, p. 48). As a result, he perceived culture as a system the substance of which is formed by the interlacing PMS.

PMS, a notion taken from the communication theory of culture based on linguistic communication models, is a specialized form of interaction. Interaction is a movement; in a multitude of ways, it is related to human existence. A human dwelling place is a site where activities associated with human existence are concentrated. A list of PMS is a system of ten mutually intergrading constants. Their matrix is the map of culture (Table 1). An active human being gives the PMS an appropriate form; thus, the PMS constitute the substance of culture, but they also affect the sites of human activities (Figure 1).

\section{Map of culture - matrix of human activities}

The map of culture is a matrix which systematizes human activities, reflected in the (hypothetical) city (Hall, 1987, p. 200). Table 1 shows types of human activities emerging from different combinations of interacting PMS. The PMS are listed in the left-hand column of Table 1, with each one being given a short explanation below its name. The upper row of the table shows relational (attributable) PMS equivalents; these indicate more concrete spheres and aspects of the interrelationships between human activities. For example: writing, communication, telephones, etc. form a communicational scope of PMS interactions, while exchange is the economic "orbit" of PMS interactions. The recreational scope of PMS interactions is the active or passive participation in arts and sports. This is

${ }^{3}$ For anthropologists, culture is long enough as a way of life of some communities, the sum of learned patterns of behaviour, attitudes, tangible objects (Hall, 1987, p. 43). 


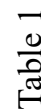

\begin{tabular}{|c|c|c|c|c|c|c|c|}
\hline & 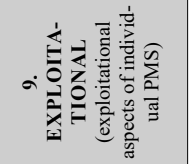 & 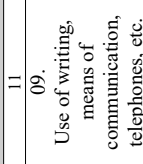 & 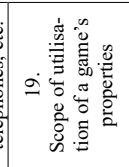 & 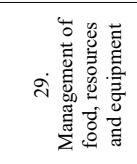 & 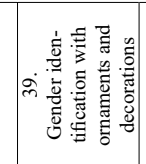 & 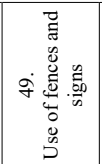 & 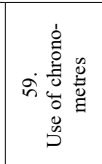 \\
\hline & 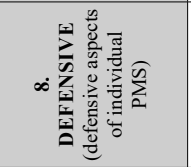 & 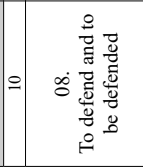 & 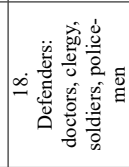 & 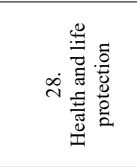 & 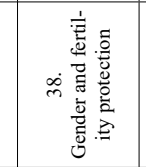 & 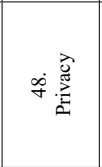 & 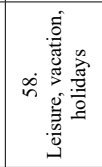 \\
\hline & 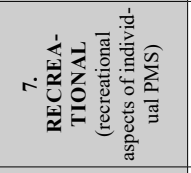 & 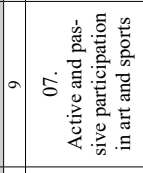 & 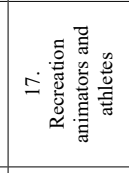 & 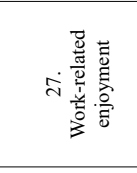 & 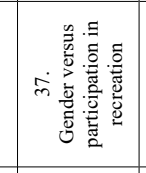 & 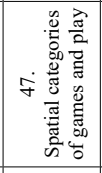 & 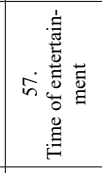 \\
\hline & 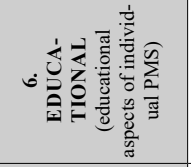 & 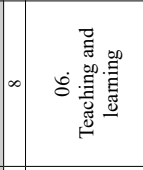 & 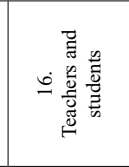 & ㄴ. & 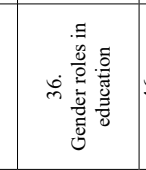 & 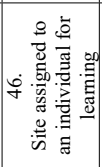 & 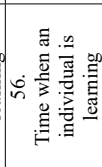 \\
\hline & 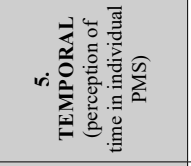 & ñ & 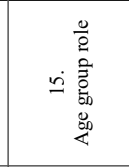 & 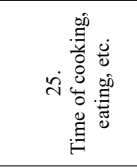 & 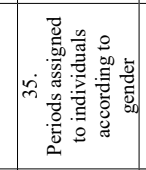 & 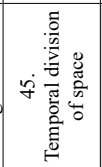 & \\
\hline & 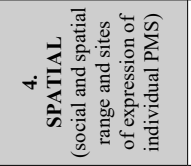 & 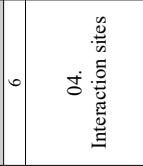 & 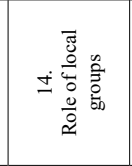 & 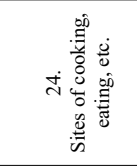 & 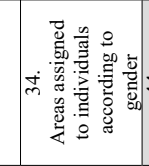 & 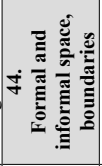 & 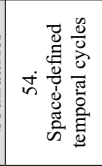 \\
\hline & 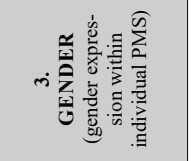 & 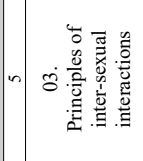 & 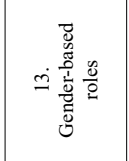 & 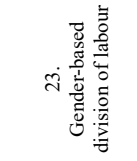 & 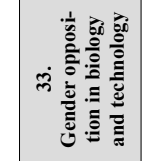 & 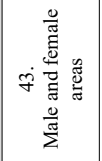 & 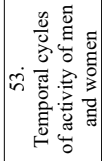 \\
\hline & 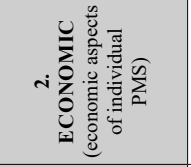 & 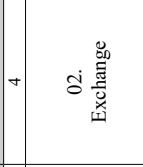 & 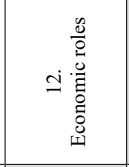 & 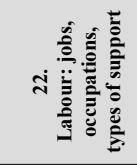 & 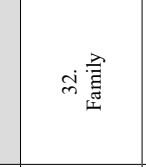 & 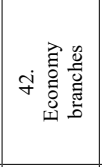 & i. \\
\hline & 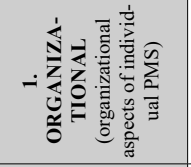 & 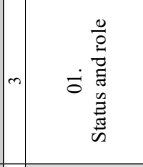 & 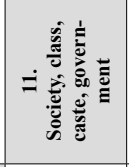 & 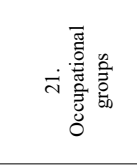 & 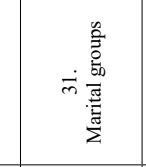 & 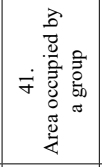 & 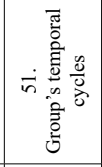 \\
\hline & 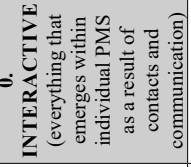 & 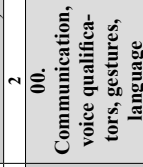 & 章 & 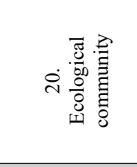 & 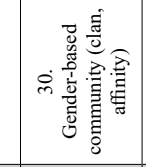 & 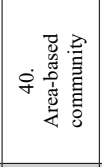 & 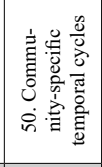 \\
\hline & 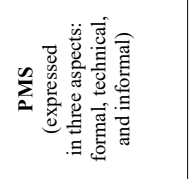 & 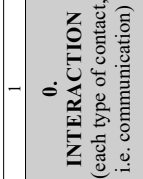 & 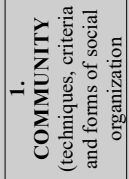 & 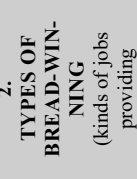 & 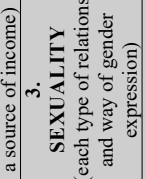 & 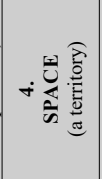 & 的 \\
\hline
\end{tabular}




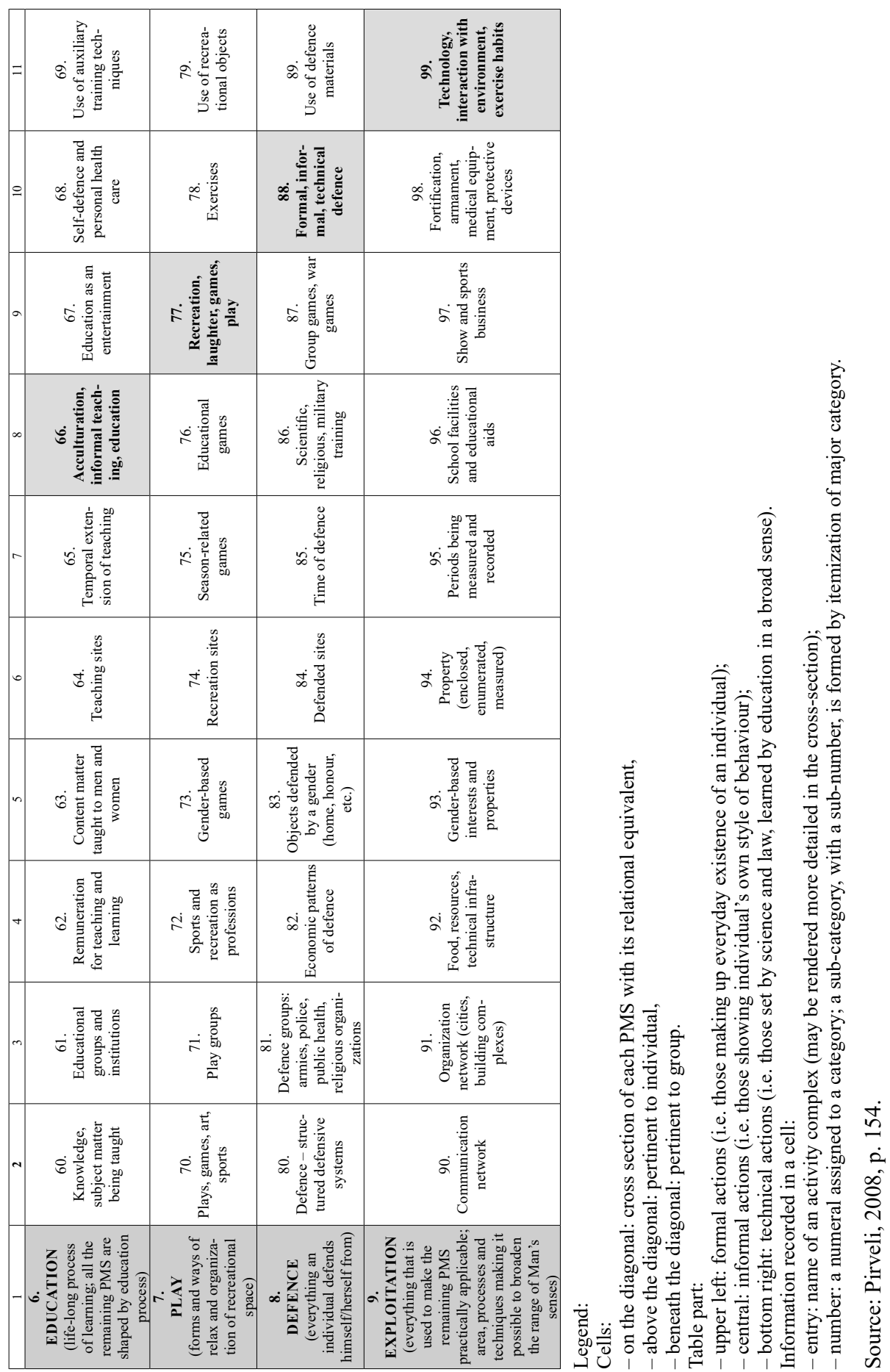


reflected in functional-spatial structures and in the occupational make up of local communities as well as in leisure-related activities.

The cells in the diagonal (from the upper left-hand corner to the lower righthand corner of the table) are formed at the intersection of each PMS with its relational equivalent. The cells above the diagonal pertain to an individual, whereas those beneath the diagonal concern a group. For example: recreation is provided to a group by singers and athletes who are organized into music bands, sports teams, and theatre ensembles.

The upper left-hand part of the table shows formal activities (i.e. those which make up day-to-day existence of a human); the middle part summarises informal activities (i.e. those expressing individual's behaviours); the entire lower righthand part is devoted to technical activities (i.e. those which are prescribed by science and law, and are learned through education in a broad sense - not limited to schools only). Each category is separate. However, related activities have been placed in adjacent cells.

The map of culture consists of one hundred numbered major cells. Each entry in a cell represents a complex activity. Each activity may be itemised and broken down into endless number of components. Each numeral, however, is permanently associated with a major sphere of human activities: 0 , Interaction; 1 , Association; 2, Subsistence; 3, Sexuality; 4, Territoriality; 5, Temporality; 6, Learning; 7, Play; 8, Defence; 9, Exploitation. Each of one hundred categories can be easily divided by 10 , and each of the emergent sub-categories can be further divided by 10 , hence we have: 80 - structured defence systems (social defence); 80, 2 - economic aspects of social defence; 80,5 - its temporal aspects, etc. The final result is a multi-layered table, as each entry placed in a cell under a particular number may be expanded vertically (not horizontally).

The system has a theoretical basis in the form of a finite list of Primary Message Systems and human activities as derivatives of their interactions. The entire matrix is written with contentless entries, which provides the map of culture with a universal character. Information accumulated in the numbered entries of the map renders different cultures comparable, while empirical models focused on culture are often not able to attain such comparability. Descriptions of material equivalents of PMS bring the hypothetical city to life (Figure 1).

\section{Material aspects of PMS}

The map of culture is a sui generis cultural equivalent of the multiplication table or of the periodic table of elements. It serves as a basis for the essence of any culture, including the city. Each culture creates its own town, because the town is 
a spatial reflection of human needs, i.e. it is a place where their material aspects are concentrated ${ }^{4}$.

Each Primary Message System (PMS) has its own material aspect on the basis of which one may see its physical form. The material aspect - for example of gender differences is a difference in clothes, the material aspect of labour being represented by tools. The time and the space are measured with instruments. Play is materially represented by toys, books representing education; even social position has its own material representation (socio-topography). Thus a scientist concerned with studies on human settlements can derive cultural parameters from studying spatial designates of interacting PMS. Table 2 presents a more detailed, albeit incomplete, description of material aspects of PMS from the standpoint of the place of their concentration (Figure 1).

Table 2

\section{Selected material aspects of PMS}

Each society and community has its own management system. Culture creates a material aspect of food (a PMS) by deciding:

- what a human being eats and when,

- how the food is prepared and what the eating place looks like,

- what vocabulary is used at the table and in food-related advertisements,

- human behaviour during meal preparation and consumption (customs),

- special customs typical of different jobs and occupations,

- evaluation of jobs in the sphere of alimentary patterns (adapted to local patterns of social organization),

- institutionalized principles of labour safety which frequently decide on the appearance of a site and clothing of food industry personnel,

- process of food processing and meal preparation in public and private spaces,

- interior decoration and size of a kitchen, a dining room, a cellar (describes both cultural features of a site and its users and determines the image of the city in the visitors' consciousness).

Eating culture (here: in the city) reflects distant fields such as specialised:

- constructions,

- interior decoration,

- range and selection of food products sold wholesale and in smaller quantities,

- methods of foodstuff sorting,

- kinds and features of household appliances,

- production cycle directly related to both food production and equipment necessary in food production, processing and consumption.

Eating culture is reflected in the urban spatial space as:

- spatial-functional structure of facilities directly related to food, sanitary requirements, opening hours,

- kinds of household appliances and food and the sites of purchase thereof,

- kinds of services rendered by food industry,

- arrangement, size, interior decoration of spaces used for eating in public and private buildings,

${ }^{4}$ An exception is a typical politicized city, e.g. a city typical of soc-realistic urban planning. In the politicized city, human needs reflect urban forms, as the form is superimposed by ideology; thus ideology, by creating needs, attempts to take the place of culture (Pirveli, 2000, pp. 17-25). 


\section{Continuation of Table 2}

- purpose and hours of frequenting different eateries,

- way of cooking and serving dishes,

- clothes, appearance and behaviour of individuals in direct contact with consumers and those who do not have such contact,

- interior decoration of and furniture in spaces used for food preparation and consumption,

- conversations, music and the atmosphere accompanying consumption as well as the etiquette of consumption,

- smells and cooking shows, etc.

Gender differences are related to physiology. Behaviour of representatives of one sex towards the others of the same sex and those representing the other gender has its origins in culture canons and determined atmosphere of the city. In each culture, different genders have their own respective behaviour patterns. Cultural sex attributes include:

- clothes,

- ornaments,

- appearance,

- hair style,

- cosmetics,

- scents,

- gestures,

- tone of the voice,

- social function,

- household and workplace duties,

- activities,

- course of proceedings

- sites off limits to one sex (a saloon, a harem, a bath, a locker room, a toilet)

- places of between-gender meeting (places to have a date or a walk, bedroom, etc.)

- games,

- competitions,

- vocabulary,

- colours, etc.

In the city, the two genders defined in this way structure and determine:

- socio-spatial features,

- customs and habits,

- atmosphere (at each level of the community),

- appearance of shop windows,

- the range of goods offered for purchase,

- diversity of stores and workshops,

- diversity of occupations, etc.

An area as a site and a territory: a site is the city itself, the territory being its non-spatial characteristics. The territory is associated by all the components. Non-spatial values of the city are defined (in accordance with the city map and users' opinion) by:

- relationships between open and built-up areas and between public and private areas,

- location of selected function relative to the area of the entire city and other functions,

- the way different functions are combined and the type of functions combined,

- sociotopography,

- physiognomic characters of buildings,

- a criterion according to which the space of the city is differentiated (e.g. ground-rent, distance measure, rhythm of life, etc.),

- directions and causes and spatial mobility of both people and functions in a place,

- the strength which attract different functions or repel one another and the centre,

- relationship between individual spatial components,

- function of an object or a place defining the centre, etc. 


\section{Continuation of Table 2}

The rhythm of life is defined by principles governing the organization of a community. It is regulated by linear time and related to the beginning and to the end of an activity; it is associated with the perception and representation of time by those who live and work in the city and also by those managing institutions. Time perception determines individual's attitude, life style, and behaviour in his/her own life space and in that of others. The rhythm is created in the city by those staying there; it is related to:

- time of meals,

- time of starting and finishing work/school day,

- time designated for breaks and leisure,

- the way and place of leisure.

The daily rhythm of the city is defined by:

- opening hours of institutions and facilities in the city (determine the spatial mobility in the city),

- natural phenomena (day and night, the seasons of the year, human attitude towards the time determining the selection of times of day and the seasons to pursue different activities in an appropriate circadian, annual, etc. cycle at different latitudes, some of them are perceived as sacred and others as profane),

- institutionalised division of time into working days, days off, and holidays, relationship towards free days and holidays (including Sunday), types of activities pursued on those days depend on perception of sacred, religious, and profane time and are tightly connected to the life style of individuals, classes, and social and cultural groups, they also determine functioning and appearance of the city in each of the seven days in a week and twelve months in a year,

- occupations, demographic parameters, world view, and life style of the inhabitants, which change both in the cultural space and in relation to climatic zones and degree of urbanization (urban versus rural areas), etc.

The essence of entertainment is relax and recreation. The need to play and to be entertained lie at the roots of a special entertainment industry; entertainment has:

- its place in everyday life,

- its own specialised cadres with appropriate attire and equipment,

- its facilities for people to play and be entertained,

- its time for both organised and private events,

- special places at homes and in the public space of the city,

- special areas in parks,

- relationships with education process,

- its own patterns and ways to create harmony and conditions for self-realisation,

- its own ways to release the energy hidden in each individual, etc.

The meaning of the term ,defence” which is a specialised activity undertaken to defend:

- one's own territory,

- faith,

- health,

- value system,

- customs,

- heritage,

- interests.

Defence is served by:

- the military (the army as protection from other societies),

- religion (as protection of an individual from dangers posed by Nature and by the individual himself/ herself),

- medicine (as protection from diseases),

- law (as protection from those disturbing the social and socio-spatial order and as protection of any kind of property). 
Continuation of Table 2

A Man protects himself from:

- forces of Nature (draught, flood, etc.),

- threats in a community,

- destructive forces in themselves.

Each nation and community, both local and a sub-culture, defines what is to be defended and by whom.

To study the defence defined in this way, information has to be collected on:

- threats to an individual and the community,

- ways an individual and/or the community defend themselves,

- attitude of an individual or the community to the threats requiring defence,

- the causes of the defence from those threats,

- spatial and functional structure of military, religious, medical, and administrative-legal objects,

- symbols and architectural characteristics of the objects identifying their functions,

- reactions elicited by the symbols associated with the defence functions,

- the degree to which people are aware of their rights and to which they exercise them, etc.

Different tools extending the range of various activities otherwise executed by the human body:

- evolution of weaponry started from teeth and fists to develop into space arms,

- clothing, housing, and heating are mechanisms allowing for controlling body temperature,

- furniture replaced the need to crouch or sit on the ground,

- transportation replaced the need to use legs and backs,

- mechanical tools (glasses, TV, telephone, books, computers, newspapers, photographs, fax machines, text messaging, Internet, etc.) transport the „voice” and the ,image” in time and space allowing the Man to see, hear, and feel more than it would be possible with the senses alone.

This category includes all the basic types of human economic activities used to produce the necessary tools and means (the paper and weapon industry, manufacture of machines, equipment, and mechanical tools; construction, textile, furniture, communication, and food industries). All those activities may be pursued in the ways giving rise to artisanal or mass production.

Characterisation of technology and material use (including information) defined in this way includes:

- culture of production,

- awareness of resources,

- resource classification,

- human attitudes towards sites at which different activities are pursued,

- human attitudes to those who pursue those activities, etc.

Places adapted to pursuing different types of activities reflect the technical and technological standards of a community and critically affect the spatial and functional structure of the city, as each production process takes place at a site / in a building that has its own physiognomic features, requires an appropriate personnel, and affects the landscape of adjacent areas.

Source: Pirveli, 2008, pp. 93-107.

The city perceived in this way is a place which concentrates designates serving as components or composites of the semantic urban space. Designates and composites may be constant, mobile, short- or long-lived, and may take on physical or non-physical form.

In other words, designates and composites are effects of human activities perceived by the senses; they are non-linguistic structural elements of the non-verbal urban language. They emerge during human activities in any epoch, as it is the axiological individual who confers the most appropriate form and content, compatible with local societal and natural conditions upon them (i.e. upon buildings, streets, squares, homesteads, institutions, objects, ornaments, items of clothing, 
tools, customs). A place becomes embedded in context, whereas a human being creates a set of rules pertaining to guard and enforce the order of things. The context is a vector of the potential of a place and is driven by cultural synergism. The context contains information on complex social and cultural manifestations of life of both an individual and a community. The context can be explored and studied exclusively via a case study, otherwise the social and cultural specificity and identity of the place (its non-spatial quality) may become broken down and annihilated in the light of fixed stereotypes formed by previous macro- or microscale studies.

\section{Morphosigns: structural units of the urban space}

\section{The origin of morphosigns}

Morphology is the science of shapes. In linguistics, morphology deals with forms of inflectionable parts of the speech. Forms of inflectionable physical parts of the urban (or urbanized) space are treated by the morphology of urban form (ISUF, 2017).

Urban form lies at the basis of the city landscape (townscape. ISUF, 2017). As a physical form, it is a system made up by three basic physical elements: 1) constructions and the associated unbuilt-up areas; 2) plots; 3 ) roads. They are non-divisible, all other physical elements of the city map being only their combinations. Physical elements of the city map are bound together by functions resulting from the aims those elements are to attain. The aims in turn stem from human needs. It is because of a certain need that a human being, when creating an urban form, shapes it so that it is capable of fulfilling the need. These three plan units and their uncountable combinations are the only physical forms of any urbanized area in the world. The contents filling the form result from its geometric parameters, physiognomic characters, and - importantly - are dependent on the underlying socio-economic processes. The city is a multiplication of urban forms united into a system. The urban form defined in this way is the maximal simplification of reality. And because all other physical elements of the city map are mere combinations of the basic elements, a scientist can explore and ponder the urban form thus understood in any spatial- temporal- socio- cultural context. The scope of the context depends on the aim of the study and the way the research objectives are being defined.

For the sake of this study, three basic physical elements of the city plan have been supplemented with a fourth one, the city greenery. Similarly to spatial equivalents of motion (a road, a street) and rest (a place: a square, a building), the city greenery has been considered to be equally tightly bound with the city at each stage of its evolution: the oldest human settlements were placed in oases; in modern cities, with their climatic and edaphic conditions far from adequate for 
the greenery, people nevertheless add this element by placing artificial trees and shrubs in concrete floors or finding other solutions to compensate for the lack of true greenery in the city. Moreover, the city greenery is a basic spatial attribute that produces the life-sustaining oxygen; devoid of oxygen, like devoid of a road, a square, and a building, a human being becomes motionless, and interactions the spatial designates of which make up the city - break down.

The urban language proposed here is not a sole example of borrowing from linguistics and of transferring linguistic insights to a different scientific area. In the urban language, graphemes are replaced by four universal morphosigns and two-component signs developed within them. The universal morphosigns are: 1) a street, 2) a square, 3) a construction, and 4) greenery. They are non-divisible structural elements of the urban space of all times. They are used by the acting individual to express spatial sequences of his/her needs (an equivalent of the linguistic phoneme). The map of culture arranges human needs into PMS (equivalents of the linguistic phonemes). The map of culture is a special type of a template of categories of human activities, the city being their spatial manifestation (Table 1).

\section{Morphosigns and signs}

In an alphabet, a letter is recorded in many different ways to emphasize and differentiate between its properties (Ń, ń, N, n, ñ,$\check{n}$ ). This is the case of a morphosign as well. The morphosign is a term proposed here to define a non-verbal graphic element (a street, a square, a construction, greenery). Morphosigns are used to model the customized space. Humans devised countless possibilities of spatial expression of individual morphosigns. Their varieties are called "signs" here. A schematic representation of signs contained in each of four morphosigns is shown in Figure 2.

The "road" and the "place", i.e. spatial equivalents of motion and rest, are translated in the city into the phenomena of the street and the square. The street is used for moving from one place to another. The square is a place to meet other people and to witness or become involved in various public actions and behaviours.

The street has only one function: motion. However, no street resembles another. Some streets have been laid out above ground, some are placed underground or inside buildings. Some are to serve only pedestrians, other have been devised to be used by vehicles (motorways, runways) or to be used by both pedestrians and vehicles (streets with sidewalks and traffic lanes). A street with shops or a street in an oriental shopping district will look differently from a park lane or a riverfront; some streets have a spatial perspective, others - covered by a roof or surrounded by windowless walls of houses - are devoid of it. A street can be adorned by windows and balconies of residential houses or offices. A street can be covered by asphalt or paved by cobblestones, mosaic tiles or some other material. A street can be broad or narrow, straight or winding, and so on. 


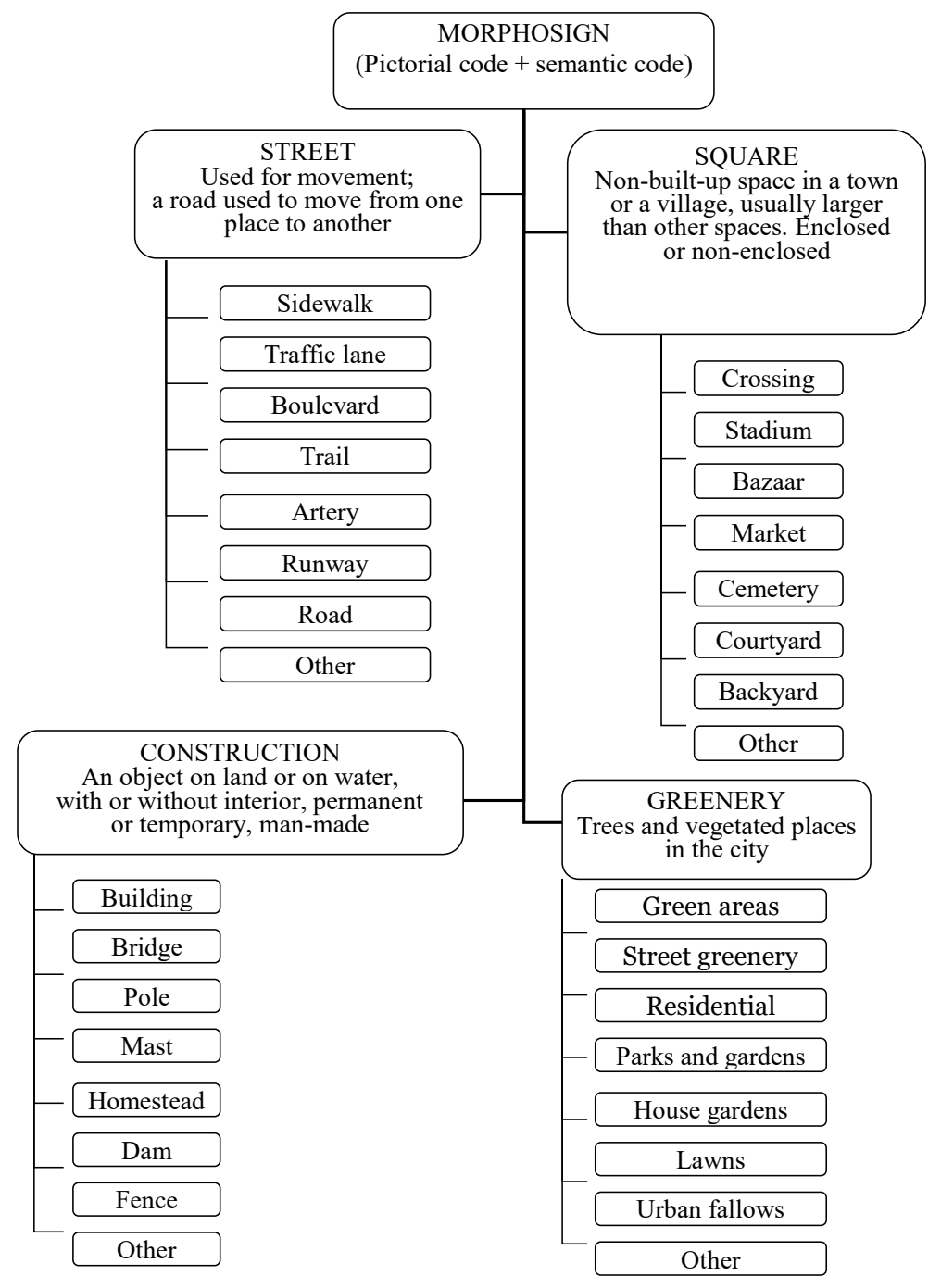

Figure 2. Morphosigns and signs

Source: Pirveli, 2008, p. 132.

The differences between streets are decided upon by three basic elements:

1. The "wall", i.e. the structure on the side (the wall is usually formed by buildings and natural or artificial sound barriers. Both the appearance and the function of the street wall are important, influenced by the way the buildings are used. Whether the "wall" composes a construction of houses, residences or offices, whether the ground floor is occupied by shops, what the nature of the shop wa- 
res is - all that affect the life of the street by deciding when the people appear there, how many vehicles move there, etc.).

2. The "floor", i.e. everything that is underfoot (traffic lanes and sidewalks, occasionally lawns and streetcar tracks).

3. The "furniture", i.e. everything that is inside (the street is usually "furnished" by trees and lamps; sometimes there are benches, phone booths, kiosks, advertisements, graffiti, etc.; the cleanness of the street is a part of the "furniture" as well).

The nature of the street depends on the size and proportions of its walls and floor.

The square is an open space in a contrasting surrounding. The nature of the square depends basically on the elements important for the street, but the meaning of those elements (the walls, the floor, the furniture) is different; different are also dimensions and geometric parameters. Particularly important is the shape of the square (rectangular, circular, short, elongated, regular, irregular). The impression left by the square is sometimes created by a single object which forms a part of the wall or is positioned inside (a town hall, a fountain, a monument, etc.). By their very nature, the squares have more furniture (trees, lamps, benches, other adornments) than the streets. The appearance of different squares demonstrates how an identity of a place can be generated by a variety of components. The square can serve a variety of functions: commerce, recreation, culture. Some squares are used as market places; even when totally covered by stalls or built-up by permanent kiosks, they still remain squares. The square can be a venue of special celebrations, can be used as a parking lot, or can be occupied by homeless or social misfits. The term "square" includes also courtyards and other open spaces contrasting with their surroundings, e.g. cemeteries, playgrounds, gardens, etc.

The building is just a type of a construction with an interior. The city has constructions without interior (masts, poles, bridges, etc). A construction can be placed on the water or on land. Apart from the interior and the situation (water, land), the differences between constructions depend on their longevity, the materials used for the structure and finishing, the size, shape, and external features, the general function, the functions served inside, and the location.

The city greenery, as a morphosign, includes all forms of vegetation, natural or introduced by Man to affect the space. Vegetation-covered places within the administrative boundaries of the city include lawns, parks, trees and shrubs in the streets, residential districts, gardens, and allotments, cemetery vegetation, fields and woods as well as potted plants in the windows and on balconies, visible from the street level.

Individual buildings, together with the space (the street, the square) and the greenery between them form groups and aggregations not only when forming a part of an institution (e.g. a monastery, a university campus), but also when they 
make up the city as an institution (Figure 1). Each individual element is at the same time a part of its surrounding. A similar approach to the city space is typical of landscape and urban design.

\section{Morphosign components}

The signs expressed within each morphosign consist of two components: the image designator and the meaning designator (Figure 3). The image designator is expressed through a pictorial code, while the meaning designator is transmitted via a semantic code.

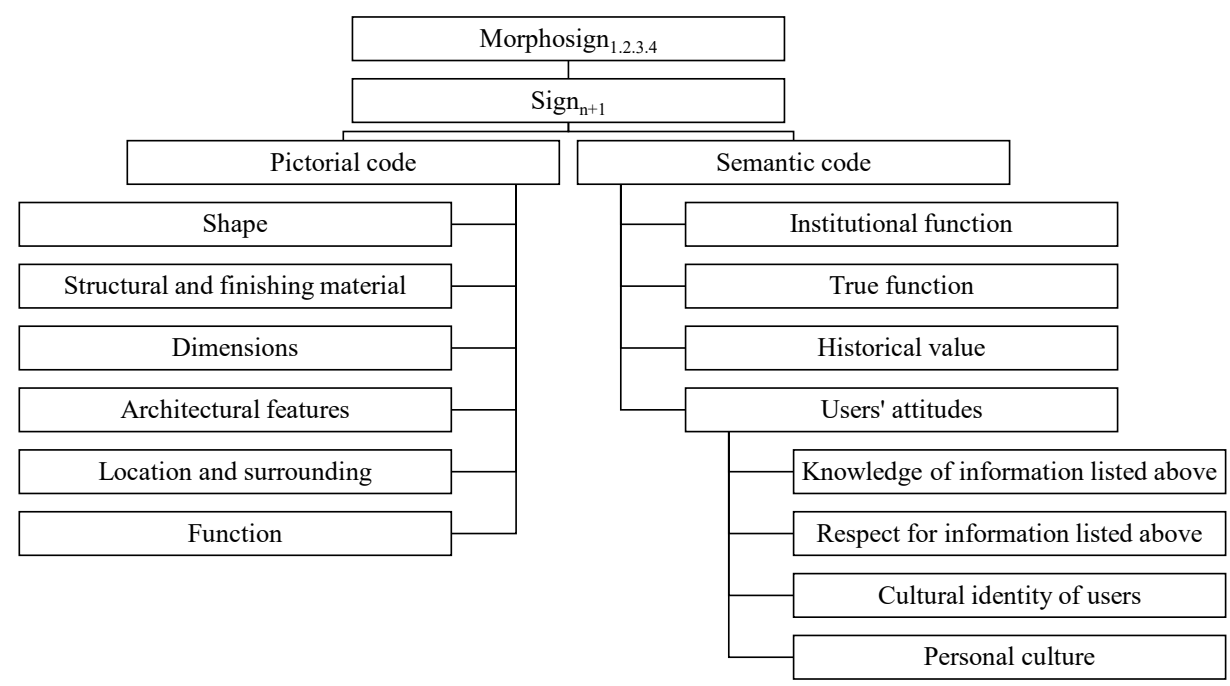

Figure 3. Structure of a morphosign

Source: Pirveli, 2008, p. 133.

The pictorial code covers everything that is visible, easily noticeable both in the city map and in the real space. The appearance of the riverfront is different than that of a side street or a pedestrian district; a residential house differs in appearance from a palace, a church, a bridge or a fountain; the central square is different from a courtyard, a playground, a cemetery or a market square; the green lawn is different than the greenery represented by potted plants on the window sill, etc. The image designator, i.e. the appearance, depends on (Figure 3):

- geometric parameters of the sign (shape, type, size),

- architectural features,

- construction materials,

- finishing materials, 
- present or future function of a given sign,

- the ambience.

The semantic code presents a more complex problem. The semantic code is invisible. It stems from:

a) the present function, which can be prescribed by local authorities or other user (e.g. a parade ground, a former residence converted to a store),

b) the original function of a given form, which has changed as a result of historical transformations (e.g. city walls of the past become a tourist attraction at present),

c) the architectural value (e.g. the "curved house" in Sopot),

d) the attitude of present users to a given physical element; the attitude results from:

d1, user's level of familiarity with information covered by a, b, c,

$\mathrm{d} 2$, in addition to familiarity, user's respect to the information covered by a, b, c,

d3, user's cultural background,

d4, user's personal culture,

d5, user's world-view and level of knowledge.

The pictorial and semantic code items require both the information source and techniques for testing. The best source for the pictorial code characteristics is an urban space (inventory method), and for the semantic code - professional documents related to local development or city planning (item a, b, c) and inhabitants (item d; quaternary; observation).

A human settlement, whether prehistoric, built in the 21 st century or still on the draftsman's board, shapes the ambience exclusively through four morphosigns. Each epoch, and each culture in an epoch, generates and establishes its own standards, its own order and pattern of combining four letters of the urban language. In other words, each epoch and the local culture that it has produced (which is communication) generates an urban space according to the principles of its own "grammar". Customized space uses - as a means of communication signs, modified by the acting humans, and the functions of those signs, adapted by individuals to the prevalent socio-cultural and other models. The spatial order and physiognomy of cities in India, China, the Hellenic Greece, and the ancient Roman Empire look differently; still different were medieval cities established according to the Magdeburg or the Neumarkt-Magdeburg town laws; settlements established in areas beyond the reaches of any law differ from Renaissance, Baroque, Hanseatic, Haussmannian, modern, or socialist-Soviet cities, differing between themselves as well. Each of those names evokes a certain silhouette of a city, its spatial arrangement and physiognomic features which are then associated with a certain urban model corresponding to the relevant historical period and culture. Broader information on those city types makes it easy to notice that, 
although there are roads, squares, greenery, and objects serving identical functions in each of them, they differ in their construction and appearance. This is a very important part of information on the semantic code of a sign (items b, c), although it does not provide any insight into the morphosign's meaning. It merely identifies the physical form in the light of supra-local and global culture.

The local community declares its attitude towards the physical forms in its immediate surroundings by the attitude of present users to a given physical element (item d). An individual's attitude to the ambience is determined by patterns of the local (or communal) social culture expressed in the space of a given locality. This is where the most important layer of the semantic code of a sign is created. The sign is a key to understanding (and decoding) the semantic code, which can be done exclusively at the case study level. The semantic code provides information on values and on the importance of a given morphosign to its major users and in the local context. The attitude of city inhabitants and all the local entities to their immediate surroundings is the basic measure of the semantic code because the city is primarily their space.

\section{Urban message: a conventionalized record of human activity}

\section{Short and long message}

Generally, everything that constitutes the interior of the city has a meaning. Its semantic value includes everything that we are able to perceive (Tomasik, 1999; Tuan, 1974; Tuan, 1975). What we see and feel in the city are the culture map key words, located and stored in the customized space (Figure 1). A signal from a city fragment which is experienced or perceived by the senses and immediately forwarded to our memory, similarly to the content matter of a book we are reading, enriches the knowledge accumulated in the memory and searches it. We receive a return signal according to which an individual behaves in a given situation and in a given place.

In the urban space, in the conventionalized record of human activities, the message vector is all information coded in or on morphosigns. Messages may be long or short. In addition to geometric and architectonic features and the characteristics resulting from their primary or secondary function, short and long messages are derived from signs that can be e.g. graphic (rendered by words and drawings on signboards), light-produced (on signboards), placed on street signs, emitted by traffic lights, etc.

A short message is aimed at producing an instantaneous human response on an unqualified assumption that the receiver understands the sign's content unequivocally and according to the sender's intention. Street names, names of institutions, building numbers, written on appropriate information plates and sign boards are intended to guide the pedestrians and motorists. Short messages include also 
other types of street information e.g. municipal transportation timetables, opening hours of institutions, number of available service windows at post office, traffic lights, signposts, among others. The semantic code of a short message is the content of the message, but also the attitude of the message addressee (and/or the sender) to the message.

A long message in the city implies a valuation context, available to those willing to learn it. Long messages are embedded in the sender's culture. It is because of long messages a place has its genius loci. Correct perception or observation of a difference in something that seems familiar at the first glance (a street, a fountain, a window, a bazaar, a coffee pub, etc.) depends on correct interpretation of the long message involved.

We try, by analogy with a familiar (culture-based) image stored in our memory, to understand what we are seeing in the cultural space-time of the city. Observations of a visible and perceived image may lead to the conclusion that known physical elements (i.e. morphosigns with pictorial and semantic codes) differ somewhat depending on circumstances. When the matter is studied in more depth, it turns out that the seemingly similar images may have, or do have, a different meaning (e.g. a fountain in front of a church versus a fountain in front of a mosque, etc.).

For example, buildings similar to Warsaw's Palace of Culture and Science can be found in Moscow, Warsaw, Chicago or New York (Figure 4). In all those cities, the buildings in question have been constructed in a similar architectonic style and are symbols of authority, power and prestige. In Moscow, such buildings are symbols of pride, as they emphasize the local symbolism either imperial or totalitarian. In Warsaw, the building exemplifies a gift from the Big Brother, while in Chicago or New York such buildings are symbols of the industrial power. However, someone else may interpret this example in a different way. Interpretation patterns emerge as a result of familiarity with the content of a meaningful and complex message.

As maintained by psycholinguistics, the receiver never assimilates $100 \%$ of sent information but only a fragment the magnitude of which depends on a situation and the receiver's intellectual capacity. The relationship between the message sent and the message received is shown in Figure 5. When the "urban form" is substituted for the "verbal language", the message is the intention of the construction designer, as shown in Figure 4 and the reception consists of interpretation by a person viewing what is shown in Figure 4. The empty circle in Figure 5 is a message sent (i.e. the building designer's intention), the black area representing the message received (i.e. interpretation). The green part indicates the size of the missed content of the message. 

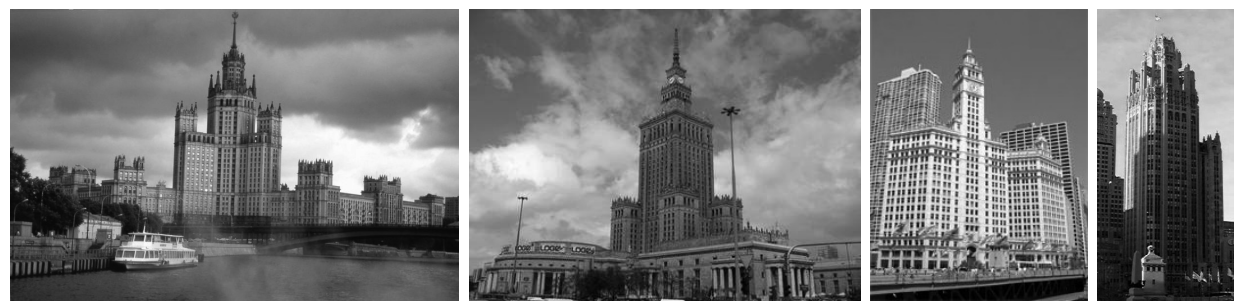

Figure 4. Location context versus meaning of an object in Moscow and Warsaw as well as in New York and Chicago

Source: Pirveli, 2008, p. 146.

We begin to understand the meaning of a long message (the green area in Figure 5 will diminish) when we are able to perceive a component of the urban culture which is most readily sensed, but most intangible and most difficult to conventionalize: the atmosphere. The city atmosphere is created by a variety of factors; it determines the relationship between the message sent and the message received (Figure 5). However, the most important for the creation of atmosphere is the attitude of city inhabitants to everything that exists (as a morphosign) and happens (as a relationship) locally.
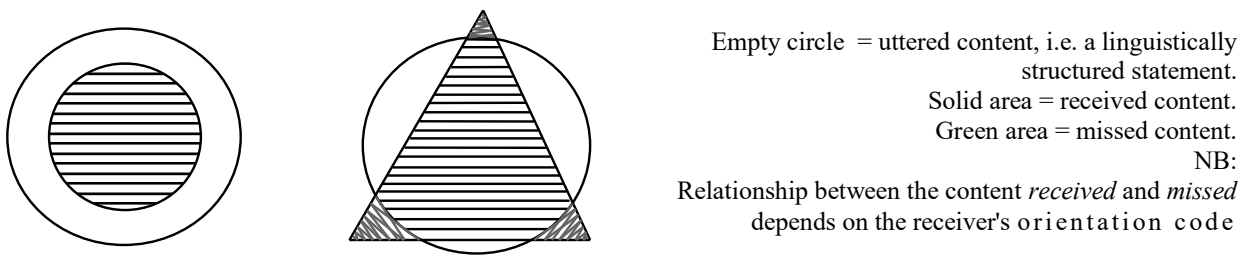

Figure 5. Relationship between the message uttered and its received content

Source: Pirveli, 2008, p. 135 (Image adapted from: Kaczmarek, 1998).

\section{Common Semantic Code (CSC) of a spatial text}

The Common Semantic Code (CSC) in the urban language, as in linguistics (Malinowski, 1983) it is a conventional system of non-verbal meaningful signs which make it possible for the spatial information to be processed and deciphered by individuals familiar with the system. A spatial text is a message defined in categories of conscious and non-conscious interpersonal relationships embedded in situations involving humans. Each situation is an outcome of a human action. The urban space is a venue of those actions and a conventional record of all types and categories of activities taking place at that site. Each activity leaves its mark, 
a trace - a long or short message. The urban space (as if a sheet of paper) binds the messages together since it is both their binding agent and synthesis (Figure 1).

The message sender is an individual possessing his/her own cultural semantic code derived from both past and present. The sender is anyone who because of his/her profession and position has been exerting influence on all the material elements present in the urban space. The senders include primarily persons involved in spatial planning, but also those participating in the creation of the spatial message. The senders of the continually updated urban space include also inhabitants of the city who, by taking care of the image and standard of their property or houses, introduce changes visible on house façades, among others (bricking-up of openings in the wall or making new openings, changing window frames, painting the external wall, adapting a flat or a house for the use by the handicapped, etc.). The authors of the message are also shop window decorators, graffiti painters or others who place various doodles and scribbles on the walls. Such signs affect the physiognomy of the city and its perception. Sign boards, advertisements, billboards, graffiti, scribbles on the walls - all the components of a street gallery create a specific and very interesting line of studies on the urban space semantics. It seems that those graphic components supplement the message recorded in the city by providing information useful for answering questions such as whom? what? whose?

The receivers are the people living in the present, those who are actually using the city. Thus, the receivers are the city inhabitants, tourists, and those who - because of their respective professions - are involved in the city matters. The receivers know, or think they know and feel, the city because of living there and possessing information about it from the literature, mass media, or oral tradition.

The sender and the receiver, i.e. individuals living or only working in a city can descend from that or the other (e.g. ethnic) culture. Even if descending from a different culture, they also create a smaller or larger part of the urban message. By staying within the space modelled by a culture different than their own they process also their own social and cultural characteristics to attain the best adaptation to the local context. This is an activity which enriches cultural aspects of the spatial context of the urban message. In this way each city is a unique example of a specific cultural synergy.

The text of the urban message is embedded in the sender's and receiver's culture. Their familiarity with the CSC dictates how correctly they will read the message released by the sender and intercepted by the receiver. Numerous factors generating urban atmosphere and a major part of the CSC include:

a) canons and customs defining rules of behaviour in a given place and in a given situation, set by culture; 
b) customs and rules defining models of behaviour in a given place as well as the degree of compliance to the models;

c) inhabitants' attitudes to the city as a whole and to its various parts;

d) physiognomic characteristics of the city and interior of different institutions and places serving particular functions;

e) opening and closing hours of different institutions and facilities;

f) attitude of the staff working for institutions to visitors;

g) lifestyles, social and economic status of inhabitants (visible also on the faces, in gestures, speech, etc.);

h) attitudes of inhabitants to themselves to visitors and to those who "look differently" (because of the skin colour, clothes, physical and mental fitness);

i) sounds (speech, music, noise) heard in the city and smells;

j) human behaviours when in anonymity;

k) human behaviours in interaction with subordinates (including parentchild, teacher-pupil, etc. relationships);

1) popular and unpopular places, their location, and - if possible - the cause of popularity or unpopularity;

m) system of governance pursued by the local (and/or central) authorities;

n) compatibility between the local governance and expectations of the users;

o) climatic conditions, topography, etc.

To decode the CSC of the urban message means to detect and reveal the local factor which has shaped the letters of the urban language. The urban language is mute, soundless but when we get to the core of the full semantic code, it will reveal itself, full of expression, and even shouting with joy and crying in sadness.

\section{The composite scanning method}

The linguistic language transmits not the language itself, but linguistically organized messages. The urban language transmits not the morphosign itself, but intentions of the sender and the receiver with respect to the function of the morphosign. Each urban form has developed its own language, i.e. its spatial order. The urban language is a technique of releasing messages, coded in the urban space, regarding needs and problems, strengths and weaknesses of authors and users of the spatial message. The task of the urban language is to find a Common Semantic Code (CSC) between and its users.

When using the composite scanning method to study an urban form, the scientist becomes an artisan who scans a dense layer of symbols, reports on the objective or physical urban space (the detailed inventory method) and on the everyday reality based on his/her own observations and responses to questionnaires collected in a given place. The report on the composites scanned is an 
in-depth description of the image of the place; it is also an interpretation of the place's interior, as viewed from the culture map perspective.

The scientist's attitude, required by the method, is extremely important. Much depends on the scientist's open-mindedness with respect to perceiving those culture features that are hidden in the physical form. On the other hand, although the visible form may seem familiar, the scientist is ready to view it from the local cultural perspective.

The perception of the city as a spatial manifestation of all activities is a type of composite scanning of the semantic space of the habisphere (a term derived from the word habitat). Composite scanning of a space produced by social interactions suggests generation of a socio-cultural profile of the image being scanned, where the composites (component designates) are the material aspects of an individual's activities, as shown in table 1 . Information on the composites should be derived from the objective environment and by authors and users of a fragment scanned by the scientist. The task involves at first decomposition, followed by re-synthesis, of the (urban) space. Defragmentation and synthesis make it possible to record the pictorial code of a morphosign making up the space in question, and to penetrate the semantic code.

The specificity of the method is that it combines information that is "objective" and "subjective" (whatever the meaning of those terms) and that is synthesizes the information to create a profile of a site being scanned (see section: Morphosign components). The method combines several techniques applicable to:

- collection of information on composites of the case under study,

- ordering the information by certain agreed-upon criteria,

- processing the information to meet the objective.

Information on mobile, permanent, short- and long-lived composites which are physical or non-physical should be collected in the field by:

- inventory (of morphosigns in the culture map),

- photographic documentation (wide-angle and close-ups photographs of selected fragments),

- polls (questionnaires addressed to inhabitants, passers-by, service providers and customers), and

- observation (of human behaviours).

The degree of detail and the manner of ordering the information determine the utility of the materials collected and their repeatability (whether they will be used once or many times; the monitoring baseline). Whatever the decision, it should make it possible to retrieve the required information fast. Fast retrieval of information is facilitated by filing and coding the data using the codes applied to the map of culture.

The composite scanning method involves reproduction of the surface layer of a place (i.e. its most readily observable part) to generate a social profile of the 
city, with numerous cultural linkages. The method is very tedious, time-consuming, and multifaceted. It seems, however, to be the only way to explore the site of cultural synergies and to generate an updated, holistic, and objective vision of the city, complete with picturing the culture of its users.

Let us make a reference, again, to linguistics, particularly to the first and the second function of the language. According to the first function, the language is a means of communication. The function of a physical image of the spatial message is similar. The second function of the language is, in addition to being the means of communication, a tool for thinking. The urban language, communicating via non-verbal means, is a message; it is a sequence of human activities and a human product. The function of the urban language (urbslingua) as a cultural system is the transfer of local urban culture in time and space.

\section{The metaphor as an interpretation}

A human being learns to read and write; the teacher - an individual whose professional experience and qualifications exceed those of a student - checks a text written by a student, pointing out their weaknesses and strengths. The student, when being shown errors, strives to improve spelling or eliminate other mistakes in, e.g., syntax, vocabulary, formatting, etc. In the city, a misspelling has its equivalent in the location of a function in an inappropriate place. Spatial order or chaos can be likened to spatial expression of syntax. The richness of the vocabulary in the spatial text is manifested by the abundance of signs selected to correctly express similar functions. Moreover, the urban space, similarly to a literary text, is governed by certain formatting principles. The urban space formatting requirements are laid out in documents recommending the uses the space it to be put to (e.g. spatial management plan which, when approved by a relevant body, becomes a law). On occasion a similar document may produce erroneous "formatting". This happens when the authors of spatial plan decide on the use of the space without consulting local people, overestimate model solutions, or disregard local socio-cultural, socio-economic and other factors resulting from valuation of natural resources.

The purpose of checking a spatial text is not to find a culprit, but to reveal the source of the error in order to give more weight to the strengths, to provide space for improvement, and to minimize the weaknesses. Perception of a customized space through human activity template leads (observers, scientists, institutional planners, etc.) to associating the erroneously recorded physical element with an activity it is a spatial manifestation of. An excess of weaknesses in a spatial text activates regression of the city, social and economic decay, and degradation of the space; it engenders stagnation and/or social aggression. Regeneration is a tool with which one brings back the socio-economic equilibrium and, as a result, 
brings the decaying or dead part of the city back to life. A balanced application of the strengths of spatial text, along with correct communication between users, lies at the base of the required (by almost any human settlement) regeneration and sustainable development of the city.

\section{Bibliography}

Galeria (2017). Stownik języka polskiego PWN. Retrieved from: http://sjp.pwn.pl/lista.php?co =galeria.

Giddens, A. (2002). Nowoczesność i tożsamość. „Ja” i społeczeństwo w epoce późnej nowoczesności. Warsaw: Wydawnictwo Naukowe PWN.

Hall, E. (1987). Bezgłośny język [The silent language]. Warsaw: Państwowy Instytut Wydawniczy.

ISUF (2017). Glossary. International Seminar on Urban Form. Retrieved from: http://www.urbanform.org/glossary.html.

Kaczmarek, B. (1998). Mózg, język, zachowanie. Lublin: Wydawnictwo Uniwersytetu Marii Curie-Skłodowskiej.

Malinowski, B. (1983). Problem znaczenia w językach pierwotnych. Warsaw: Wiedza Powszechna.

Pirveli, M. (2000). Podstawy teoretyczne urbanistyki socrealizmu. XIII Konwersatorium Wiedzy o Mieście. Łódź: Łódzkie Towarzystwo Naukowe, 17-25.

Pirveli, M. (2008). Miasto - przestrzeń semantyczna. Szczecin: Wydawnictwo Zapol.

Rapoport, A. (1984). Culture and urban order. In: J. Agnew, J. Merser, D. Sopher (eds.), The city in cultural contest (pp. 50-75). London, Boston: Allen \& Unwin.

Tomasik, W. (1999). Inżynieria dusz: literatura realizmu socjalistycznego w planie "propagandy monumentalnej". Wrocław: Wydawnictwo Uniwersytetu Wrocławskiego.

Tuan, Y.F. (1974). Topophilia: a study of environmental perception, attitudes, and values. PrenticeHall, Englewood Cliffs.

Tuan, Y.F. (1975). Images and mental maps. Annals of the Association of American Geographers, $65(2), 205-213$.

Wallis, A. (2001). Definicja miasta. Symbole. In: M. Malikowski, S. Solecki (eds.), Socjologia miasta-wybór tekstów (pp. 76-82). Rzeszów: Wydawnictwo Wyższej Szkoły Pedagogicznej.

\section{Język miasta (urbslingua) - metoda fenomenologiczna}

Słowa kluczowe: fenomenologia, mapa kultury, język miasta, morfoznak, metoda

Streszczenie. W artykule scharakteryzowano język miasta (urbslingua) jako fenomenologiczną metodę. Jest ona osadzona w nauce o mieście (urban study). Metoda ta stanowi narzędzie służące do identyfikacji zjawisk przestrzennych występujących $\mathrm{w}$ przestrzeni miasta $\mathrm{i}$ badanych $\mathrm{w}$ ujęciu holistycznym. Miasto jest postrzegane jako komunikat 
przestrzenny, a przestrzeń miejska jako wielowarstwowy tekst przestrzenny. Ów tekst jest napisany morfoznakami. Morfoznak (odpowiednik językowego grafem) jest niepodzielnym elementem strukturalnym zurbanizowanej przestrzeni. Morfoznak wyłania się z formy morfologicznej miasta (zdefiniowanej przez ISUF); desygnuje wszystkie typy działalności człowieka, których przestrzenne odbicia znajdują się w mieście. Przestrzeń miejska jest ich syntezą i spoiwem. Morfoznaki są powiązane przez kulturę, która jest nawigatorem miejskiego porządku przestrzennego, tj. jest syntaxem.

\section{Citation}

Pirveli, M. (2017). The Urban Language (Urbslingua) - Phenomenological Method. Marketing i Zarządzanie, 4 (50), 25-51. DOI: 10.18276/pzfm.2017.50-03. 